MATEUSZ JANIK

Polityka nie-polityczności nieme zwierzęta i posthumanizm

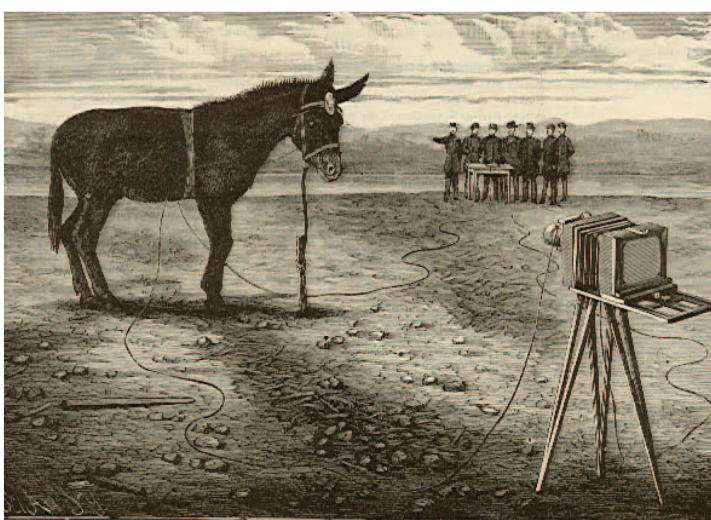

Fig. 1.-INSTANTANEOUS PHOTOGRAPHY.-BEFORE THE EXPLOSION

Jednym z najpoważniejszych nieporozumień, które narosły wokół pojęcia posthumanizmu, jest przekonanie, zgodnie z którym humanizm jest centralnym punktem odniesienia w sporze o etyczny i ontologiczny status człowieka. Polski przekład książki Rosi Braidotti Po człowieku pozwala spojrzeć w krytyczny sposób na tę silnie zakorzenioną w polskiej humanistyce potrzebę ocalenia człowieczeństwa. Nawet jeśli książka ta nie rozwiewa jednoznacznie wspomnianego nieporozumienia, to pozwala dostrzec, na jak wątłych podstawach jest ono umocowane. Jak przekonuje Braidotti, krytyczny i emancypacyjny potencjał perspektywy posthumanistycznej ujawnia się 
właśnie w momencie, w którym to, co po człowieku, zrywa z humanistyczną mitologią, poszukując nowych, nieludzkich (ahumanistycznych) ujęć ${ }^{1}$. Co ważne, nie mamy tu do czynienia z zadaniem wymagającym wejścia w nową postludzką rzeczywistość, lecz raczej z próbą zmapowania relacji, w których człowiek już na ontologicznym poziomie jest jednym z wielu członów, wcale nie najważniejszym ani nawet nie nieodłącznym, procesualnie rozumianej sieci relacji obejmujących zjawiska społeczne i przyrodnicze, nieludzkie formy życia, technologię, ekonomię i ekologię, a wreszcie struktury i praktyki poznawcze ${ }^{2}$. Jednak w swoich próbach przekroczenia antropocentrycznej, szowinistycznej gatunkowo, opresywnej i reakcyjnej wizji człowieka, Braidotti raz po raz napotyka trudności wynikające z faktycznej hegemonii bytu ludzkiego, który dzierży niepodzielną władzę nadawania znaczeń, określania wektorów relacji, wyznaczania sfer etycznej widoczności czy politycznej sprawczości. Jest rzeczą dosyć symptomatyczną, że największe dyskusje wokół zaproponowanej przez nią teoretycznej konstelacji budzi pytanie o naturę, o nieludzkie zwierzęta, zwłaszcza zaś sugestia, że mogą one dysponować ontyczną i etyczną autonomią, która nieuchronnie podważa ich apolityczny (czy wręcz kontrpolityczny) status.

W tradycji filozoficznej nieludzkie zwierzęta sytuują się poza polityką, w najlepszym przypadku stanowiąc jej przedmiot, w najgorszym zaś zasób. Jednak polityczny charakter odpolitycznienia nieludzkich zwierząt wydaje się oczywisty, choćby dlatego, że jest ono artykułowane zawsze w polu polityki. Jest jednocześnie niejasny, nie tylko z powodu paradoksalnej polityczności tego, co niepolityczne, lecz również ze względu na to, że narzuca ono kłopotliwe pojęcie „specyficznie ludzkiego” sposobu istnienia. Niejasność tkwi przede wszystkim w tym, że sam podział na to, co ludzkie i to, co nieludzkie nie pokrywa się z rozróżnieniem pomiędzy tym, co polityczne i niepolityczne. Nie tylko ze względu na to, że istnieją nieludzkie zwierzęta, którym cechę polityczności można przypisać,

1 Warto podkreślić, że Braidotti dostrzega nie tylko arbitralność i partykularność samej siatki pojęciowej składającej się na dyskurs humanistyczny, lecz również ich instytucjonalne umocowanie, które gwarantuje ich reprodukcję w przestrzeni akademickiej (zob. Braidotti 2014, 321-322).

2 Nie jest to wcale oczywiste i sama Braidotti wielokrotnie wskazuje na potrzebę skonstruowania czegoś na kształt przedsięwzięcia zdolnego zastąpić niedokończony projekt nowoczesnego humanizmu. Warto jednak rozróżnić pewne przedsięwzięcie polityczne od diagnostyki - dzięki temu łatwo zauważyć, że nowe rozpisanie stawek tak teoretycznego, jak i politycznego dyskursu ma raczej performatywny, nie zaś deskryptywny charakter. To, co nadchodzi stanowi echo zawsze obecnej „posthumanistycznej” kondycji, którą humanizm stara się egzorcyzmować. 
lecz także ze względu na to, że humanistycznie zorientowana polityka opiera się na ciągłym wytyczaniu granic, odbierającym cechę polityczności również ludziom ${ }^{3}$.

Gdy mowa o człowieczeństwie, nowoczesność pozoruje pewien ruch w stronę uniwersalności, przedstawiając kondycję ludzką jako pewną uniwersalną cechę, wzbijającą się ponad partykularne interesy i poszczególne pozycje. Ma ona gwarantować powszechność dostępu do sfery polityki czy też - odwrotnie - ma być powszechną podstawą ludzkiego bytu. Już choćby z tego powodu pytanie o to, jaki charakter ma różnica ustanawiana poprzez przypisanie temu, co nieludzkie niepolitycznego charakteru i zarezerwowanie polityki dla „specyficznie ludzkiej” egzystencji wydaje się istotne. Otwiera ono możliwość myślenia o politycznym wymiarze tych sfer, które określa się mianem niepolitycznych (czy wręcz apolitycznych, w znaczeniu zwykłej niedialektycznej nieobecności tego, co polityczne). Ważnym jest, aby podkreślić w tym miejscu, że choć punktem wyjścia jest dla nas pewna określana biologicznie różnica, to chodzi tu o wszystkie sposoby istnienia, którym przypisuje się radykalnie heterogeniczny charakter względem polityki (w tym sensie natura jest tylko jednym z elementów apolitycznego łańcucha ekwiwalencji, w którym znajdujemy również takie ogniwa jak „sfera prywatna”, „ekonomia”, „praca reprodukcyjna” itd.). Równie istotne jest to, że podnosząc kwestię posthumanistycznej polityki, nie sytuujemy się w obszarze jakkolwiek rozumianej futurologii. Posthumanizm jako określenie tego, co nadchodzi po człowieku albo poza niego wykracza, jest zawsze obecną możliwością i jednym z elementów kształtujących humanistyczny projekt nowoczesności - stanowi jego przeznaczenie, które ten nieustannie stara się odegnać jako koszmar i swą karykaturę. Staje się to doskonale widoczne, gdy spojrzymy na jeden z dyskursów założycielskich nowoczesności: kartezjanizm.

3 Bardzo dobrym przykładem pojęcia służącego do wytyczania takiej granicy jest „dialog” - kategoria uznająca za akceptowalne, a tym samym godne uznania w nowoczesnej przestrzeni politycznej jedynie niektóre pozycje, niektóre formy zabiegania o swoje interesy i wreszcie tylko wybrane grupy, zdolne spełnić ustanowione zawczasu warunki uczestnictwa w „dialogu”. Zjadliwą krytykę dialogiczności polityki przeprowadza między innymi Anna Zawadzka (2011). Inną strategią stosowaną do depolityzacji jest naturalizacja, której przykładów dostarcza między innymi Przéńniona rewolucja Andrzeja Ledera (zob. zwłaszcza afirmowana przez Ledera jako kategoria opisowa - figura gombrowiczowskich ludzi-psów, opisująca międzywojenne chłopstwo - Leder 2014, 101-105). 


\section{Widmo hybrydy}

Z punktu widzenia nieludzkich zwierząt filozofia kartezjańska cały czas stanowi dla nas praktyczny i obowiązujący punkt odniesienia. Faktyczna kategorią ontologiczną opisującą kondycję zwierząt z perspektywy relacji, jaka łączy je z ludźmi, nadal jest ciało-automat, dostarczająca surowców maszyna. Hegemoniczność tej perspektywy polega między innymi na tym, że stanowi ona punkt wyjścia dla jakiejkolwiek teorii zwierzęcości, niezależnie od tego, czy jest ona wypowiedziana, czy nie. Co więcej, nawet jeśli odrzucimy opis zwierzęcia jako pewnej przezroczystej etycznie i emocjonalnie maszyny (to znaczy opis jego rzeczywistej pozycji w porządku globalnego kapitalizmu, którego nieodłączną częścią jest przemysłowa hodowla zwierząt), konieczna jest pewna praca dekonstrukcji. Tak rozumiana próba wyjścia poza człowieczeństwo przez uznanie znaczacego charakteru nieludzkich form istnienia może spotkać się z podwójnym szantażem. Może ona zostać bowiem zaatakowana albo z perspektywy antropocentrycznej wzniosłości, albo też ontologicznej naiwności. Innymi słowy, uznając znaczenie nieludzkiej egzystencji, narażamy się na zarzut zezwierzęcenia bytu ludzkiego - prostej projekcji przyrody na „królestwo ducha”, zrównującej człowieczeństwo i naturę. Z drugiej zaś strony, każdej próbie skonstruowania pewnej wspólnej płaszczyzny zamieszkiwanej przez ludzkie i nieludzkie zwierzęta grozi uczłowieczenie zwierzęcości - kolejna wariacja na temat dobrego dzikusa, będącego ucieleśnieniem tyleż szlachetnej co naiwnej prawdy o człowieku.

Te dwie formy możliwej krytyki posthumanistycznego podejścia do zwierząt wyznaczają również horyzont krytyki kartezjańskiego czy też postkartezjańskiego humanizmu. Horyzont ten jest o tyle problematyczny, że istnieje jeszcze inna, wyparta czy raczej zapomniana linia kartezjanizmu, która dziwnie przypomina posthumanistyczną perspektywę atakowaną dziś z liberalno-konserwatywnych pozycji (zob. Fukuyama 2004; Bielik-Robson 2014). Uwidoczniła się ona najwyraźniej w reakcji scholastycznych obrońców form substancjalnych, odrzuconych przez Kartezjusza na rzecz mechanicystycznego opisu świata.

Jednym z najbardziej symptomatycznych przypadków wspomnianej reakcji jest Gisbertus Voetius, jeden z najbardziej znanych krytyków filozofii kartezjańskiej. Wśród licznych oskarżeń, jakie Voetius sformułował pod adresem Kartezjusza i tzw. Nowych Filozofów będących zwolennikami mechanicystycznego opisu świata, większość dotyczyła bezbożności i odstępstwa od arystotelizmu. Szczególne miejsce wśród nich zajmował jednak problem zastąpienia form substancjalnych 
określających wewnętrzne własności rzeczy ${ }^{4}$ dynamiczną siecią wzajemnych oddziaływań wpisujących istnienie w porządek mechanicznych przyczyn i skutków. Zdaniem Voetiusa konsekwencją takiej perspektywy było całkowite zniesienie porządku naturalnego oraz podziału na to, co konieczne i przygodne. Co gorsza, świat opisany za pomocą mechanicznych oddziaływań otwierał jego zdaniem ontologiczne wrota wszelkiego rodzaju mutacjom i hybrydom. Odrzucenie form substancjalnych znosiło jakąkolwiek możliwość wyraźnego odróżnienia tego, co istotne od tego, co przygodne, zacierając wszelką ontologiczną różnicę pomiędzy rzeczami. Świat pozbawiony form substancjalnych, pisał Voetius, zaciera możliwość czynienia jakiegokolwiek istotnego rozróżnienia

pomiędzy wilkiem, owcą, wielorybem, słoniem, wężem, kamieniem drzewem, tojadem, pszenicą, słońcem, księżycem i ziemią, nie wspominając o zegarach, drewnianym koniu trojańskim, byku Falarisa, latającym gołębiu Archytasa, głowie z brązu [wykonanej przez] papieża Sylwestra, czy mówiącym posągu w domu Alberta Wielkiego (Voetius 1648, 872).

Enumeracja ta miała nie tylko unaocznić chaos wynikający z porzucenia form substancjalnych. Jej właściwym celem było przekonanie czytelników, że w świecie wyznawców nowej filozofii, której Kartezjusz miał być jednym z głównych orędowników, potworność staje się normą, nie zaś wypaczeniem zasługującym co najmniej na potępienie. Jak przekonuje Voetius, „potwory nie mają przyczyn per se ani też określonych (ponieważ przyczyny przygodne nie są żadnymi przyczynami), jako że są one porażką i skrzywieniem natury" (cyt. za Van Ruler 1995, 46) - w świecie pozbawionym substancjalnie rozumianego bytu jednostkowego stają się one jedynym możliwym sposobem istnienia. Przykładem takiego wynaturzenia jest muł, będący potomstwem konia i osła, którego bezpłodność świadczy o braku właściwej mu formy substancjalnej.

W mechanicystycznym obrazie świata, który w kartezjańskiej filozofii zastępuje arystotelesowski świat przyczyn celowych i scholastycznych form substancjalnych, wszelka zmiana nie wynika z oddziaływania substancjalnie osadzonych własności rzeczy, lecz pochodzi z zewnątrz, jest zawsze wielością przyczyn zewnętrznych, czyniąc rzeczy poszczególne jedynie wypadkową, zbiegiem okoliczności. Jak wskazuje Van Ruler, który szczegółowo zrekonstruował spór Voetiusa z Kartezjuszem, takie przejście sprawia, że pojęcie natury traci cały swój normatywny ładunek. W świecie

4 Przez formę substancjalną Voetius rozumiał prosty substancjalny akt, ustanawiający wraz z materią poszczególną rzecz, taką jaką jest ona ujmowana w sobie (zob. Van Ruler, 1995, 61). 
mechanicznych oddziaływań oraz złożonych relacji ruchu i spoczynku „naturalne procesy nie są już opisywane w kategoriach przedstawiających sobie to, co naturalne i nienaturalne. Nawet to, co naturalne, a więc „normalne« staje się warunkowe”. Z punktu widzenia scholastyki „taki świat rządzony jest przez to, co nienaturalne, zewnętrzne przyczyny i skutki, wcześniej zarezerwowane jedynie dla sztucznych procesów" (Van Ruler 1995, 136-138). Natura okazuje się wiecznym stanem wyjątkowym, w którym żadna rzecz nie posiada właściwych sobie cech.

\section{Potworna niemota}

Jeśli dokonamy przekładu tej argumentacji na kategorie polityczne, otrzymamy tezę, zgodnie z którą kartezjańska nauka pozwala na wprowadzenie do dyskursu (rozumianego zarówno konceptualnie, jak i performatywnie) koncepcji radykalnego przekształcenia. Nie ma bowiem powodu, dla którego, zmieniając kompozycję ciał oraz ich wzajemne relacje ruchu i spoczynku, nie moglibyśmy skończyć w świecie całkowicie odmiennym od tego, jaki znała kalwińska ortodoksja, której głosem był Voetius. Dla teologów jest to przerażająca koncepcja, ponieważ świat arystotelesowskiej scholastyki to świat, w którym nie tylko rośliny i zwierzęta, lecz również mężczyźni i kobiety, jak i całe klasy społeczne znają swoje miejsce, miejsce, do którego mogą zostać sprowadzeni i sprowadzone, czy to świadomie i dobrowolnie, czy to siłą. Porzucenie tego świata oznaczałoby wkroczenie na ścieżkę egzystencjalnego permisywizmu i całkowitego chaosu; ontologiczną anarchię, świat rządzony przez nieprzerwanie mutujące hybrydy.

Paradoksalnie, stanowisko przedstawione przez Voetiusa jest słuszne. Nowożytna nauka rzeczywiście dała możliwość pomyślenia radykalnej zmiany sposobu organizacji świata na poziomie ontologicznym, zmiany znoszącej wszelkie teologicznie (a wręcz każde transcendentne) umocowane formy władzy, otwierając drogę dla nowych (zarówno bardziej demokratycznych, jak i opresywnych) form istnienia (równocześnie naturalnych i społecznych $)^{5}$.

Jednak wystarczy nawet pobieżna lektura pism Kartezjusza, aby zauważyć, że metafizyczna struktura jego dzieła wygląda zupełnie inaczej. Kartezjusz wpisuje bowiem mechaniczny opis fizycznego świata w cały

5 Myślicielem, który w dobie nowożytności posunął się najdalej w wyciąganiu konsekwencji odrzucenia scholastycznego substancjalizmu form jest Spinoza, który wyprowadził pojęcie przekształcenia z obrębu ściśle metafizycznych rozważań, sytuując je w centrum swojej teorii politycznej. 
aparat gwarancji znoszących możliwość przekształcenia. Nie tylko każdy byt utrzymuje się w istnieniu w niezmienionej postaci, lecz również postać ta jest gwarantowana przez zewnętrzną instancję, Boga, którego władza jest po wielokroć bardziej absolutna niż scholastycznie niuansowane panowanie voetiańskiego Boga form substancjalnych. Mechanicyzm jest tylko fragmentem systemu kartezjańskiego, systemu wyposażonego również w takie figury filozoficzne jak res cogitans czy też Bóg-AbsolutnyPrawodawca, którego moc tożsama jest z mocą suwerena. Niemniej istnieje powód, dla którego Voetius mógł pozwolić sobie na tak śmiałą enumerację, zrównującą zwierzęta, rośliny i ciała niebieskie w jednym łańcuchu ekwiwalencji - nie wymieniając w nim jednocześnie ludzi. Był on możliwy, ponieważ w gruncie rzeczy różnica pomiędzy zwierzęciem a człowiekiem ani przez chwilę nie zostaje naruszona w kartezjańskiej metafizyce - nie opiera się ona bowiem na wewnętrznej kompozycji ciała i stosunkach ruchu oraz spoczynku, lecz na rozróżnieniu na ciało i myśl. Nie oznacza to jednak, że rozróżnienie to nie jest wpisane w cielesność, wprost przeciwnie; w rozprawie o metodzie Kartezjusz podaje bardzo wyraźne kryterium, które pozwala nam zorientować się, że podział na to, co ludzkie i nieludzkie ma wybitnie praktyczny charakter:

Jest to rzecz nader godna uwagi, że nie ma ludzi tak tępych i głupich, nie wyjmując nawet szaleńców, iżby nie byli zdolni zebrać do kupy rozmaitych słów i ułożyć z nich zdania, którym zdołają wyrazić swą myśl; przeciwnie zaś, nie ma innego zwierzęcia, choćby było najdoskonalsze i najbogaciej obdarzone, aby dokazało tegoż samego. A nie dzieje się to dlatego, iżby im nie stało organów. Widzimy, iż sroki i papugi mogą wymawiać słowa tak jak i my, a wszelako nie mogą mówić jak my, to znaczy objawiając, iż myślą to, co mówią. Przeciwnie, ludzie, którzy, będąc z urodzenia głusi i niemi, pozbawieni są, tyleż albo więcej co bydlęta, organów służących innym do mówienia, zwyczajni są wymyślać sami z siebie jakieś znaki, i za pomocą nich porozumiewają się z osobami, które przebywając zwyczajnie w ich towarzystwie, mają możność wyuczenia się tego języka. To świadczy nie tylko, iż zwierzęta mają mniej rozumu niż ludzie, ale że nie mają go wcale, widzimy bowiem, iż potrzeba go bardzo mało, aby umieć mówić (Kartezjusz 2002, 40).

Jest to jeden z najbardziej intensywnych fragmentów Rozprawy, w którym możemy dostrzec równoległą względem metafizycznych rozstrzygnięć zasadę regulatywną antropologicznej maszyny. Zwierzę jest nieme, nie tyle przez przypadek, lecz z definicji. Nie mówi, nawet jeśli używa słów (jak papuga). Człowiek mówi. Nawet ludzie, którzy nie używają słów, potrafią mówić (używając gestów albo innych form niewerbalnej 
komunikacji). Istotna jest tutaj przede wszystkim konstrukcja ujawniająca istnienie czegoś, co można by nazwać (uzupełniając Habermasowski repertuar roszczeń ważnościowych) roszczeniem do bycia usłyszanym. Zwierzę nie mówi nawet gdy je słyszymy, nie dlatego, że nie posiada ono zdolności komunikacyjnych, lecz ze względu na to, że uchybia ono samym swym zwierzęcym istnieniem owemu roszczeniu, czyniąc je niespełnialnym - gdyby tylko je spełniło, przestałoby być zwierzęciem, a sama oś przeciwstawiająca sobie to, co ludzkie i nieludzkie, uległaby załamaniu.

\section{Ryk}

Jednak nieludzkie zwierzę nie jest jedynym bytem, który możemy usłyszeć przy jednoczesnej odmowie jego wysłuchania. Rzeczywisty problem nie tkwi bowiem w odpowiednim wytyczeniu granic, lecz w wyjaśnieniu sposobu, w jaki one funkcjonują, stanowiąc jednokierunkowe domknięcie aparatu dominacji, umożliwiającego odtworzenie w porządku politycznym relacji podmiotowo-przedmiotowej. Wyjaśnienie tego rodzaju wymaga przyjęcia materialistycznej perspektywy, pozwalającej rozpisać dystynkcję antropologiczną na relacje władzy, które ona ustanawia.

W tym miejscu warto choćby na chwilę zwrócić się ku marksowskiej analizie kapitalizmu6. W Rękopisach filozoficzno-ekonomicznych Marks rozpisuje kondycję robotnika na osi wyznaczanej przez bieguny przyrodniczej zwierzęcości i specyficznie ludzkiej egzystencji. Chociaż układ ten jest umocowany na całkiem odmiennych podstawach niż kartezjańska oś duch-maszyna, to jego właściwy efekt jest niemal identyczny - robotnik, wyalienowany w swej pracy, w swym ciele i w swym życiu, wiedzie zwierzęcą egzystencję, nie mogąc wyartykułować „politycznie akceptowalnych” (tzn. zrozumiałych, mających jakiekolwiek deliberatywne znaczenie) roszczeń. Należy zwrócić tutaj uwagę na dwie rzeczy. Pierwsza dosyć oczywista - polega na oderwaniu dystynkcji antropologicznej od biologicznej cezury i wyrażeniu jej za pomocą materialnie umocowanej relacji, będącej wyrazem historycznie określonego stosunku wyzysku oraz gwarantującego go aparatu prawno-politycznego. Dużo istotniejsze jest jednak to, że marksowska diagnoza nie narzuca w sposób konieczny konsekwencji wysunięcia roszczenia do bycia zrozumianym albo do zys-

6 Na możliwość posthumanistycznej reinterpretacji Marksa zwraca uwagę Joanna Bednarek (2014). Rosi Braidotti z kolei nie szczędzi słów krytyki pod adresem dominujących $\mathrm{w}$ dwudziestym wieku form marksizmu i jego politycznych inkarnacji, skłaniając się raczej ku antyhumanistycznym, postspinozjańskim odczytaniom materializmu historycznego (zob. Braidotti 2014, 66-77; 130-133). 
kania rozpoznania w polu politycznym. Nawet sama idea politycznej organizacji proletariatu nie jest celem jako takim. Zwierzę, które zna i używa słów, nadal nie jest w stanie mówić. Robotnicy, którzy używają języka politycznych instytucji, nadal pozostają robotnikami. Organizacja polityczna jest istotna o tyle, o ile umożliwia zniesienie systemu spychającego robotnika do poziomu siły roboczej, politycznie niemego zasobu. W pewnym sensie marksizm stanowi spełniony koszmar Voetiusa nie ma tu już mowy o egzorcyzmowaniu rzeczywistego ruchu, znoszącego obecny stan - jak w przypadku zachowawczego gestu Kartezjusza. Przeciwnie, stawką okazuje się dopuszczenie do głosu niemych potworów (których potworność przejawia się przede wszystkim w tym, że jedyny artykułowany dźwięk docierający na wyżyny polityki - mogącej pozwolić sobie na luksus człowieczeństwa - to obalenie panującego porządku).

Warto również zauważyć, że znajdujemy się tu na antypodach nowoczesnej polityki opartej na dyskursie reprezentacji, uniwersalności prawa, czy nawet emancypacji (rozumianej jako wyzwolenie poddanej represji, autentycznej istoty). Pozycja zajmowana przez marksowskiego robotnika jest pozycją niemego zwierzęcia, niezdolnego do wyartykułowania jakiegokolwiek zrozumiałego politycznego roszczenia. Niezdolność ta wynika z faktu, że jego polityczne istnienie implikuje obalenie systemu wyzysku, który ustanawia i określa charakter nowoczesnej polityki. To właśnie w tym znaczeniu zwierzęcość nie jest kategorią biologiczną, lecz polityczną. Z punktu widzenia nowoczesnych politycznych instytucji nieme/nieludzkie zwierzę jest niepolityczne po prostu dlatego, że nie może ono zgłaszać żadnych roszczeń, które dałyby się zrozumieć bez stwarzania zagrożenia dla samego istnienia społecznego ciała nowoczesności. Rozpoznanie w zwierzętach osób, istot zdolnych do cierpienia i posiadających swoje własne, autonomiczne interesy, stawia na politycznej wokandzie choćby tak podstawowy postulat jak zniesienie ich przemysłowej hodowli - podobnie jak uznanie politycznej podmiotowości robotników musiało oznaczać poważne potraktowanie obalenia systemu opartego na prywatnej własności środków produkcji i pracy najemnej.

\section{Obraz}

Historia fotografii dostarcza okrutnego świadectwa podsumowującego politykę opartą na antropologicznej dystynkcji. W 1878 roku Charles Bennett opracował technologię pozwalającą podnieść światłoczułość żelatynowych płytek używanych w fotografii. Pod pewnymi względami wprowadzona przezeń innowacja oznacza początek współczesnej fotografii 
- od tej pory zdjęcia można było wykonywać z czasem naświetlania poniżej jednej sekundy, uchwytując nowy, nieznany dotąd ludzkiemu oku świat momentalności ruchu. W czasie jednej z prezentacji nowego typu fotografii wykonano zdjęcie tyleż osobliwe, co przerażające. Jak na ironię przedstawiało ono muła - hybrydę stanowiąca ucieleśnienie Voetiańskiego przypadkowego potwora, zagrażającego naturalnemu porządkowi.

W celu pokazania, jak działała wspomniana innowacja techniczna zdecydowano się sfotografować niezwykłą scenę. Do głowy zwierzęcia przytroczono bawełniany woreczek wypełniony dynamitem, który połączono specjalnym przewodem z aparatem fotograficznym. W chwili, w której migawka została otwarta, by uchwycić obraz, nastąpiła eksplozja. W ten sposób powstało zdjęcie przedstawiające bezgłowy korpus muła, który za chwilę upadnie na ziemię. Oparta na spojrzeniu relacja władzy zostaje niemal utożsamiona z porządkiem przyczynowo-skutkowym: muł traci głowę dokładnie w momencie, gdy aparat uchwytuje jego obraz. Zwierzę traci twarz, staje się nieme pod naporem spojrzenia ${ }^{7}$.

Fotografia ta uchwytuje doskonale figurę zwierzęcia, które staje się nieme i nieludzkie na mocy pojedynczego gestu spojrzenia, ustanawiającego relację pomiędzy nim a światem społecznym. Zdjęcie wskazuje na kluczowy ele-

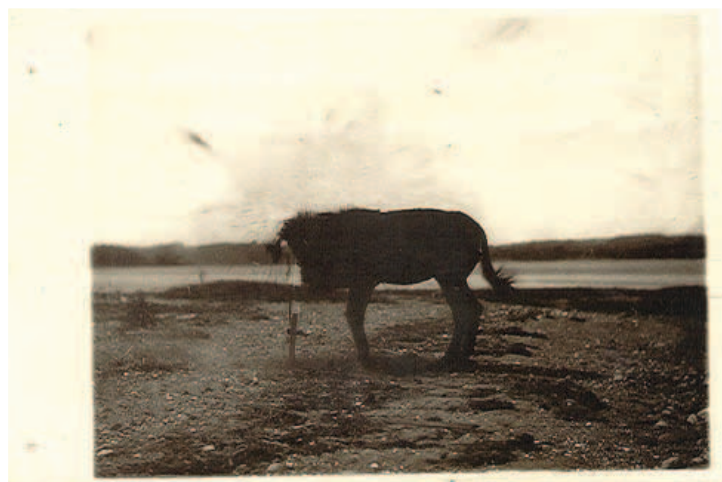
ment sposobu, w jaki zwierzęcość działa w polu społecznej, albo też po prostu ludzkiej egzystencji. Staje się ono niemą bestią, traci swój rozum oraz twarz całkiem dosłownie.

7 Opis przeprowadzonego w czerwcu 1881 roku „eksperymentu” pochodzący z krótkiej notki opublikowanej w numerze „Scientific American” z września 1881 roku rozpoczyna się słowami: „potrzeba unicestwienia bezwartościowego muła stała się okazją do zaprezentowania pouczającej lekcji uczniom szkoły wojskowej stacjonującym w Willet's Point". Do notki dołączono między innymi dwie ryciny, jedną prezentującą muła „uzbrojonego" w ładunek wybuchowy i podpiętego do aparatu fotograficznego za pomocą przewodu. Druga rycina, wykonana na podstawie fotografii, przedstawia tego samego muła tuż po eksplozji, „bezgłowe stworzenie, wciąż jeszcze przez chwilę stojące zanim jego ciało zwaliło się na ziemię" (Scientific American 1881, 194). 


\section{Wykaz literatury}

„Instantaneous Photography.” 1881. Scientific American, 24 września. Bednarek, Joanna. 2014. „Emancypacyjna obietnica posthumanizmu.” Praktyka Teoretyczna, http://www.praktykateoretyczna.pl/joannabednarek-emancypacyjna-obietnica-posthumanizmu/.

Bielik-Robson, Agata. 2014. „Wylewanie dziecka z kąpielą.” Krytyka Polityczna, http://www.krytykapolityczna.pl/felietony/20140917/ wylewanie-dziecka-z-kapiela.

Braidotti, Rosi. 2014. Po cztowieku. Tłum. Joanna Bednarek i Agnieszka Kowalczyk. Warszawa: Wydawnictwo Naukowe PWN.

Fukuyama, Francis. 2004. Koniec cztowieka: Konsekwencje rewolucji biotechnologicznej. Tłum. Bartłomiej Pietrzyk. Kraków: Wydawnictwo Znak.

Kartezjusz. 2002. Rozprawa o metodzie. Tłum. Tadeusz Boy-Żeleński. Kraków: Wydawnictwo Zielona Sowa.

Leder, Andrzej. 2014. Prześniona rewolucja: Ćwiczenie z logiki historycznej. Warszawa: Wydawnictwo Krytyki Politycznej.

Van Ruler, J.A. 1995. The Crisis of Causality: Voetius and Descartes on God, Nature, and Change. Leiden: Brill.

Voetius, Gisbertus. 1648. Selectarum Disputationum Theologicarum, t. I. Utrecht-Amsterdam.

Zawadzka, Anna. 2011. „Odmowa dialogu.” Bez Dogmatu 88. 
Mateusz Janik - filozof, tłumacz. W 2013 roku obronił pracę doktorską poświęconą ontologii politycznej Benedyka Spinozy.

\section{Dane adresowe:}

Mateusz Janik

ul. Popiełuszki 17b/62

01-595 Warszawa

e-mail: hawana13@gmail.com

\section{Cytowanie:}

M. Janik, Polityka nie-polityczności - nieme zwierzęta i posthumanizm, „Praktyka Teoretyczna” nr 4(14)/2014, http://www.praktykateoretyczna.pl/PT_nr14_2014_Polityki_ popkultury/08.Janik.pdf (dostęp dzień miesiąc rok)

DOI: $10.14746 /$ prt.2014.4.8

Author: Mateusz Janik

Title: The Politics of Non-Politics - Mute Animals and Posthumanism 